\title{
Reflecting the past
}

\section{Unsatisfied with merely halting environmental destruction, some conservationists are trying to reconstruct ecosystems of the past. Emma Marris travels back in time with the rewilders.}

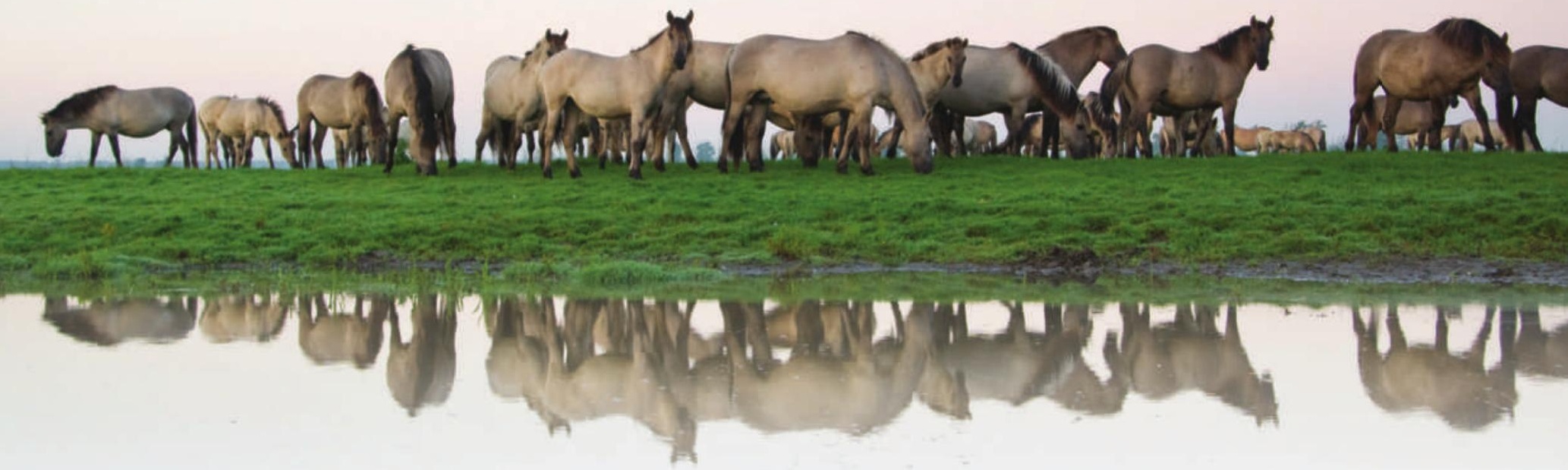

enced off from the modern Dutch countryside is a scene that looks more like a diorama in a natural-history museum than a typical central-European park: a plain is dotted with wild herds of large mammals. Empty of humans and haunted by eagles, it is a vision of a distant past on some of the newest land on Earth - the reserve was only reclaimed from the sea in 1968. It's called the Oostvaardersplassen, and the visionary behind it is Frans Vera, a tall, greying government scientist from Staatsbosbeheer, the organization responsible for overseeing Dutch nature reserves.

Vera designed the 6,000-hectare reserve to replicate Europe's prehistoric past. That has meant 'rewilding' the area, populating it with the kinds of creature that lived there many thousands of years ago. That some of these creatures - including wild horses called tarpans, and aurochs, wild ancestors of modern cattle - are extinct, was not enough to stop Vera. In the 1980s, he went shopping for substitutes. He acquired Konik horses, believed to be descendants of wild Tarpans, from Poland. For the aurochs, he substituted Heck cattle, a line developed by two German brothers in the early twentieth century from a number of cattle breeds with the intention of mimicking auroch features. The herds number in the hundreds and graze alongside a red-deer population of about 2,000. Next, Vera would love to get his hands on some European bison and boar.

Vera's reasons for developing this eclectic menagerie might not be immediately clear. It isn't a tourist attraction; few people are granted entry, although viewing points for bird watchers dot the periphery. It has, however, succeeded as a conservation area; several bird species rare to Western Europe, such as the white-tailed eagle, have moved in. Vera says that it is also a large science experiment, designed to test his theories about how European landscapes used to look. But he has struggled to keep the reserve open and lacks the funding for graduate students. The project generates very little systematic data or scientific papers, adding to its mystique.

\section{Pleistocene parks}

Vera's isn't the only rewilding project. Schemes in locales as diverse as New Zealand, Saudi Arabia and the Russian Far East aim to do more than hold the line against further environmental destruction (see 'Lost landscapes'). They are attempting to recreate the ecological workings of previous eras, often those of the Pleistocene from 2 million to 10,000 years ago. Advocates for Pleistocene rewilding would restore, if they could, the age when nature lived wild and large, when mastodons, sloths and three-tonne wombats heaved their bulk around Earth, and predators were big, fast and ubiquitous. Because many of the fauna in these systems are now extinct, the schemes often turn to proxies to fill abandoned roles: grazing, browsing, defecating and culling the herd.

Critics, however, say that the projects are more sentiment than science. Dustin Rubenstein, an ecologist at Columbia University in New York, argues that placing proxy animals in a modern landscape is not the same as turning back the clock, and could spell trouble ${ }^{1}$. These ecosystems have changed and existing species have evolved in the thousands of years since megafauna extinctions. Attempting to fill gaps that closed long ago with proxy animals can generate unpredictable results. "It is the difference between the known and the unknown," he says. Proxy animals, he suggests, could become invasive pests, or escape their parks and cause trouble with local landowners, who would then turn against the conservationists. Moreover, Rubenstein worries about how the projects in Europe and elsewhere are being run and says that information about them is not being disseminated. "We're not seeing the results in the peer-reviewed literature." Without anything being published, he says, rewilders can't dispel worries about the consequences of such proxy introductions.

Vera says that the complaint has merit, but that the project doesn't have enough money or personnel to monitor and publish on the wildlife in the reserve. William Sutherland, an ecologist at the University of Cambridge, UK, with a special interest in documenting conservation experiments, says that it's a common, frustrating occurrence. "It is as if you can only find out about details of a cancer treatment by going round the wards with the doctor," he says. Sutherland says that Vera and other rewilders - along with many other conservation biologists - are "too busy conserving to have the time to monitor and publish".

The only way to learn about the Oostvaardersplassen is to go there. Nestled between windmills, small dairy farms, a dyke and the city of Almere, it is, above all, totally unexpected: a Serengeti of sorts with vast, grassy 
plains where wild horses, cattle and red deer move in massive herds. Two white-tailed eagles perch near their nest, an enormous tree house of bone-white branches. Spoonbills, greylag geese, ibises and many other European bird species converge on the marshes. From the taller grass, a white and orange mist of butterflies explodes in front of Vera's van. And on one edge of the park, an abandoned calf - its eyes glazed, its knees wobbly - faces death.

Vera watches the calf for a few moments, then reaches for his radio and calls one of the reserve's staff members, who will come and kill it. Although the park is supposed to support nature in its raw form, the Dutch public considers letting animals starve to death too cruel to stomach, so Vera has worked out an agreement with the government that provides swift dispatch to sick and starving animals. Every year, $10-20 \%$ of the large herbivores in the park die from natural causes or are killed by humans. But their corpses in turn support other animals. Vera was perhaps the only person not surprised to see a Eurasian black vulture, long absent from the area, appear in the park - although its tenure was short. It strayed outside the fence and was run over by a train.

The Heck cattle at the Oostvaardersplassen could, at a pinch, be mistaken for the aurochs painted in famous Palaeolithic caves at Lascaux in southwestern France. Large-bodied and wide-horned, they come in several colours, from black to brown to beige. "For me, the point was that they not look like dairy cattle," says Vera. He wants people to see them as wild animals, and - apart from the compromise reached on mercy killings - they live a wild life, without veterinary care, supplemental feeding or even ear tags. They do what comes naturally, and in so doing they are keeping the reserve grazed down and open, turning the earth with their massive hooves and, in their wallows, creating depressions that fill with water and become mini-ecosystems.

\section{Reshaping landscapes}

Vera hopes that the Oostvaardersplassen will help to answer a couple of scientific questions: can grazers drive ecosystem processes, and will the resultant landscapes be patchy or densely forested? Vera's vision of Europe's past is of a patchy landscape, what he calls a "park-like landscape" in which any given area cycles between open grassland maintained by herbivores, thorny shrubs that sneak in where herbivores are caught napping and tree-dominated groves that grow in the shelter of the herbivore-proof shrubs.

The sequence of events could explain why oak seedlings don't grow up to be adult oaks in the shade of other trees, even though giant oaks
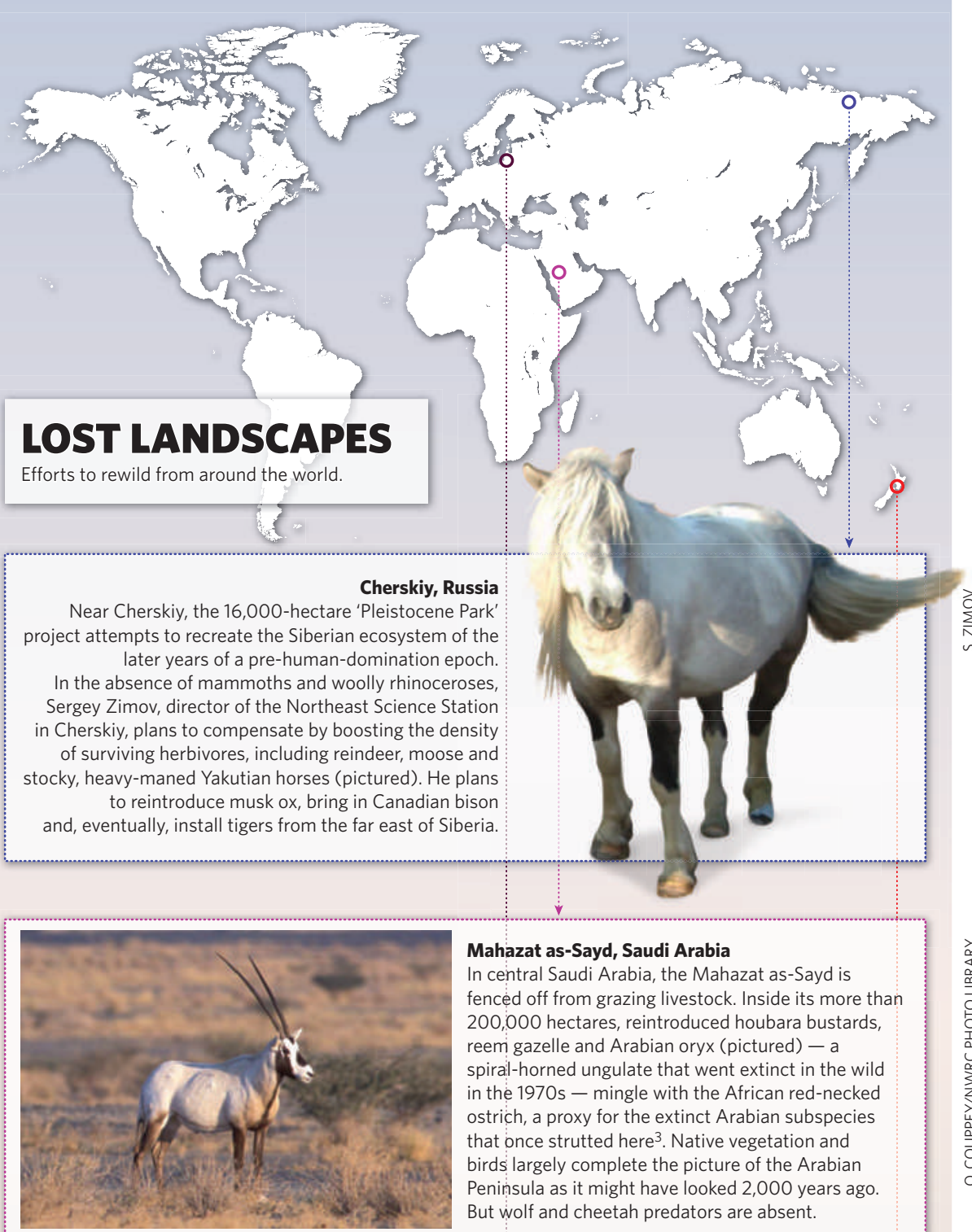

Mahazat as-Sayd, Saudi Arabia

In central Saudi Arabia, the Mahazat as-Sayd is fenced off from grazing livestock. Inside its more than 200,000 hectares, reintroduced houbara bustards, reem gazelle and Arabian oryx (pictured) - a spiral-horned ungulate that went extinct in the wild in the 1970s - mingle with the African red-necked ostrich, a proxy for the extinct Arabian subspecies that once strutted here ${ }^{3}$. Native vegetation and birds largely complete the picture of the Arabian Peninsula as it might have looked 2,000 years ago. But wolf and cheetah predators are absent.

Wellington, New Zealand

Zealandia (formerly the Karori Wildlife Sanctuary), 225 hectares in the heart of Wellington, allows urbanites to experience the country more or less as it was before people stepped ashore. A mammal-proof fence protects many rare bird species, including some, such as the little-spotted kiwi (pictured), that had not been seen on the mainland for many years. The scientists behind the reserve are toying with adding a few proxies as well - having the Australian owlet-nightjar play the extinct New Zealand

owlet-nightjar, for example. Scientific data are being collected in reams, but peer-reviewed publication lags, thanks to a dearth of time and money.

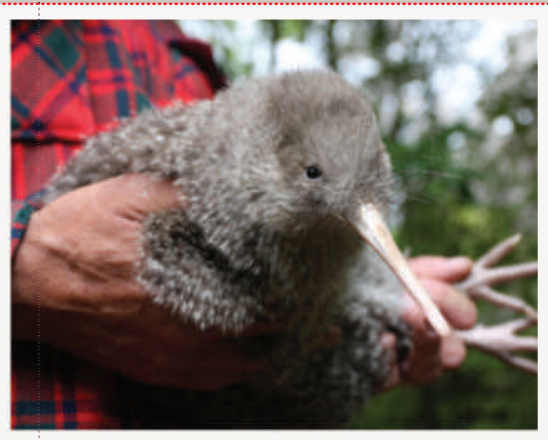




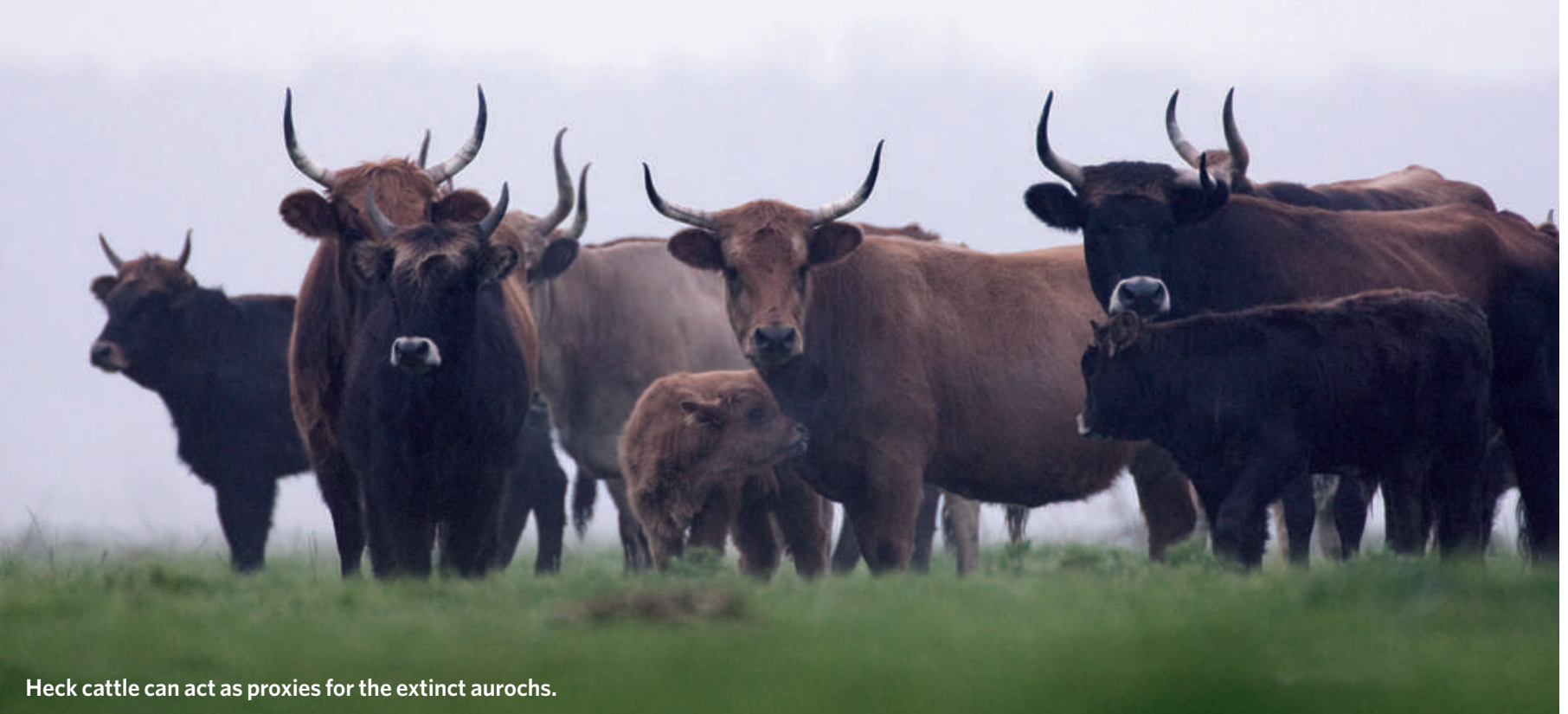

are found in all of the continent's ancient forests. Vera believes that most old oaks grew up in open areas and then saw the forest fill in around them. His is the minority view. Most scientists think a closed forest covered the continent. So far, the Oostvaardersplassen has shown that a high density of grazers can certainly affect the landscape: they have largely mowed it clean. Vera suspects that thorny shrubs will establish themselves and act as nurseries for tree seedlings, even if it doesn't happen in his lifetime.

\section{Rough approximations}

Vera's experimental set-up does have major limitations. As he and other designers readily admit, every rewilding project will be only an approximation of a past ecosystem. With taxon substitutions and incomplete sets of plant and animal functional groups, many of these systems perhaps evoke the past more than they replicate it.

The Oostvaardersplassen, for example, contains none of its lost predators, such as bears or wolves, yet other reintroduction experiments have shown that they can alter the entire ecosystem. When wolves were reintroduced to Yellowstone National Park in Wyoming, for example, the elk soon learned to feed only in areas where they could see wolves if they approached. As a result, areas with bad sight lines were soon thick with willow and cottonwood seedlings ${ }^{2}$. Perhaps this 'ecology of fear' would promote the growth of the thorny shrubs that Vera eagerly awaits. However, weary from battles over the management of the Oostvaardersplassen, he says he is in no hurry to step into the political minefield of wolf reintroduction in a country where livestock owners are a powerful political force. Instead, he says, he will wait for wolves from increasingly popular reintroduction programmes elsewhere in Europe to converge on the Netherlands. Wolves are notoriously good at covering ground, even in population-dense areas such as northern Europe. "They will come, whether we like it or not," he says.

Josh Donlan, director of the conservation consultancy Advanced Conservation Strategies in Midway, Utah, and a champion of Pleistocene rewilding projects, says that for some projects the most important motivations are not science- but conservation-oriented. Others, such as a tortoise proxy programme in the Mascarene Islands near Madagascar are "completely hypothesis driven", says Donlan, and being carefully documented. These reintroductions offer a huge opportunity to do science, he says, not only to learn about the ecology of the past, but also to feed back into the projects, "which are going to need all the information they can to be successful".

Donlan and others have proposed that Pleistocene reserves be created in North America, where African and Asian animals could fulfil the roles of the large mammals that went extinct on the continent about 13,000 years ago. The proposal would have two conservation goals. Lineages of species that have been driven to extinction would have a chance to return to North American ecosystems and start to evolve along their own unique path, and species that would themselves be saved from extinction in their home countries would resuscitate extinct processes in North America. Elephants, for example might eat large fruit such as the osage orange, dispersing their seeds naturally as mastodons and other elephant relatives were thought to do thousands of years ago. This vision of vast areas populated with camels, wild asses and lions has caused a major stir. It has generated strong responses from the public, both for and against, with many dismissing the whole idea as insane.

But Donlan says that many people are coming around to the concept. "I think that it is certainly gaining traction in the public view," he says. "Conservationists are starting to rally around this idea, almost certainly partly because it is proactive." That is, it is something that conservationists can do beyond trying to prevent development and negative change - a strategy that Donlan considers pessimistic and mostly ineffective. Rubenstein has problems with Pleistocene rewilding as it stands, but gives credit to Donlan's desire for change.

For Stuart Pimm, a conservation biologist at Duke University in Durham, North Carolina, and one of the few scientists to have set foot in the Oostvaardersplassen, the re-appearance of white-tailed eagles, breeding barnacle geese and at least one black vulture is proof that the reserve is achieving its conservation goals. "They've got it right and a lot of things have come back as a consequence," he says. As for the scientific goals, he urges a broader view. Sure, there are no control areas or replications. But at this scale, how could there be? "The idea that we have to do neatly replicated experimental design with little squares doesn't capture the whole range of what science does," he says.

Vera is approaching retirement age now, and looking for a successor to take over the job he's been doing, under various titles, for 30 years. For his retirement, who knows. Perhaps he'll consult on rewilding projects elsewhere. "I would love to find out what an elephant eats in the temperate regions," he says.

Emma Marris writes for Nature from Columbia, Missouri.

\footnotetext{
Rubenstein, D. R., Rubenstein, D. I., Sherman, P. W. \& Gavin T. A. Biol. Conserv. 132, 232-238 (2006)

2. Ripple, W. J. \& Beschta, R. L. BioScience 54, 755-766 (2004).

3. Seddon, P. J. \& Soorae, P. S. Conserv. Biol. 13, 177-184 (1999).
}

See go.nature.com/kT4vnz for a slideshow of images from the Oostvaardersplassen and an interview with the author. 


\section{Dirty pigs beat disease}

Living like a pig could be good for you, according to research showing that dirty piglets pick up 'friendly' bacteria that help them to develop robust immune systems later in life.

The results provide support for the hygiene hypothesis, which suggests that a lack of exposure to microbes in early life can affect development of the immune system and increase susceptibility to certain disorders, such as allergies and inflammatory bowel disease.

Denise Kelly, a gut immunologist at the University of Aberdeen, UK, who worked on the study, says that the results provide the first direct link between early exposure to microbes, immune health and gene expression (I. E. Mulder et al. BMC Biol. 7, 79; 2009). Until now, she says, that link had been circumstantial. "There has been a lot of hearsay around gut microbiota and how it influences immune function and susceptibility to diseases and allergies."

Although many researchers now accept the hygiene hypothesis, says Jean-François Bach, an immunologist at the University of Paris Descartes, there are still questions about how it works, including what role the microbiota has in the gut and how infection helps to protect against disease. "This paper shows that the first days of life are very important," he adds.

The researchers took 54 piglets and divided them equally between an outdoor environment, an indoor environment and isolated conditions in which they were fed antibiotics daily. The scientists then killed piglets on day 5 (neonatal stage), day 28 (weaning age) and day 56 (nearing maturity) to study their gut tissue and faeces.

The study found that $90 \%$ of bacteria in the guts of the outdoor piglets came from the phylum Firmicutes. Most of these were Lactobacillaceae, a family of bacteria known for their ability to limit intestinal pathogens such as Escherichia coli and Salmonella species. By contrast, Firmicutes made up less than $70 \%$ of the gut flora in indoor pigs and slightly more than $50 \%$ of that in isolated pigs. Pigs from these cleaner environments also had much smaller proportions of bacteria from the Lactobacillaceae.

Kelly's team also found that the differences in gut microbes affected the expression of genes associated with the piglets' immune systems. Animals raised in the isolated environment expressed more genes involved in inflammatory immune responses and cholesterol synthesis,

whereas genes linked with infection-fighting $T$ cells were expressed in the outdoor-bred pigs.

Glenn Gibson, a food microbiologist at the University of Reading, UK, says that previous studies have suggested that immune responses are linked to organisms in the gut. "This study takes a step forwards by tallying the geneexpression response into this," he says. However, he adds, because the study was carried out in pigs, there is no way to be certain that the results are relevant to humans.

Jonathan Rhodes, a gastroenterologist at the Royal Liverpool University Hospital in Liverpool, UK, points out that people with chronic inflammation of the digestive tract, known as Crohn's disease, have reduced numbers of Firmicutes, as did the cleaner piglets. But, he adds, patients with Crohn's also have reduced overall bacterial diversity, similar to the outdoor pigs, suggesting that the results might not extrapolate directly to human disease.

Kelly argues, however, that the comparable organ sizes of humans and pigs, and the similarities between the microorganisms found in their guts, makes pigs good model animals for such studies.

\section{Natasha Gilbert}

\section{Correction}

The News Feature 'Reflecting the past' (Nature 462, 30-32; 2009) suggested that wolves from reintroduction programmes might find their way to the Oostvaardersplassen reserve. In fact, the closest wolves are expanding from eastern Europe without human help. In addition, what was described as cattle 'wallows' are better termed 'scratching pits', as the cattle use their hooves to make them rather than rolling on their backs. 